\title{
Prognostic role of pretreatment blood lymphocyte count in patients with solid tumors: a systematic review and meta-analysis
}

\author{
Jiawen Zhao ${ }^{1 \dagger}$, Weijia Huang ${ }^{2 \dagger}$, Yongxian $\mathrm{Wu}^{1 \dagger}$, Yihuan $\mathrm{Luo}^{2}$, Bo Wu${ }^{1}$, Jiwen Cheng ${ }^{1}$, Junqiang Chen², \\ Deyun Liu' ${ }^{1}$ and Chengyang Li ${ }^{*}$
}

\begin{abstract}
Background: To evaluate the prognostic value of pretreatment lymphocyte counts with respect to clinical outcomes in patients with solid tumors.

Methods: Systematic literature search of electronic databases (Pubmed, Embase and Web of Science) up to May 1, 2018 was carried out by two independent reviewers. We included Eligible studies assessed the prognostic impact of pretreatment lymphocytes and had reported hazard ratios (HR) with 95\% confidence intervals (Cls) for endpoints including overall survival (OS) and progression-free survival (PFS). Only English publications were included.

Results: A total of 42 studies comprising 13,272 patients were included in this systematic review and meta-analysis. Low pretreatment lymphocyte count was associated with poor OS ( $\left.\mathrm{HR}=1.27,95 \% \mathrm{Cl} 1.16-1.39, P<0.001, \mathrm{I}^{2}=58.5 \%\right)$ and PFS (HR $\left.=1.27,95 \% \mathrm{Cl} 1.15-1.40, P<0.001, \mathrm{I}^{2}=25.7 \%\right)$. Subgroup analysis disaggregated by cancer type indicated that low pretreatment lymphocytes were most closely associated with poor OS in colorectal cancer followed by breast cancer and renal cancer.
\end{abstract}

Conclusions: Low pretreatment lymphocyte count may represent an unfavorable prognostic factor for clinical outcomes in patients with solid tumors.

Keywords: Lymphocyte, Pretreatment, Prognosis, Solid tumor

\section{Background}

An increasing body of evidence suggests that immune status, an essential biological marker, is a key factor in carcinogenesis and cancer progression. Lymphocytes, such as those in the peripheral blood and tumor-infiltrating lymphocytes (TILs) constitute one of the most important effector mechanisms of anti-tumor immunity. Tumor cells are often surrounded by immune cells,

\footnotetext{
*Correspondence: 15277006345@163.com

†iawen Zhao, Weijia Huang and Yongxian Wu contributed equally to this work and therefore share first authorship

${ }^{1}$ Department of Urology, The First Affiliated Hospital of Guangxi Medical University, 6 Shuangyong Road, Nanning 530021, Guangxi Zhuang Autonomous Region, China

Full list of author information is available at the end of the article
}

especially lymphocytes. Tumor cells are distinguishable from healthy cells by the presence of tumor antigens which provide an immunological stimulus. Lymphocytes play an important role in anti-tumor immunity by inducing apoptosis and by suppressing the proliferation and migration of tumor cells [1-3]. High numbers of TILs were shown to be associated with inhibition of tumor progression and favorable prognosis in patients with hepatocellular carcinoma [4], colorectal cancers [5], and ovarian cancers [6]. Results of a meta-analysis suggest that TILs moderately influence the prognosis in diverse types of cancer; in particular, high number of intratumoral CD3+, CD4+ or CD8+ lymphocytes was associated with a lower risk of death and progression [2]. Numerous clinical studies have revealed that peripheral

(c) The Author(s) 2020. This article is licensed under a Creative Commons Attribution 4.0 International License, which permits use, sharing, adaptation, distribution and reproduction in any medium or format, as long as you give appropriate credit to the original author(s) and the source, provide a link to the Creative Commons licence, and indicate if changes were made. The images or other third party material in this article are included in the article's Creative Commons licence, unless indicated otherwise in a credit line to the material. If material is not included in the article's Creative Commons licence and your intended use is not permitted by statutory regulation or exceeds the permitted use, you will need to obtain permission directly from the copyright holder. To view a copy of this licence, visit http://creativeco mmons.org/licenses/by/4.0/. The Creative Commons Public Domain Dedication waiver (http://creativecommons.org/publicdomain/ zero/1.0/) applies to the data made available in this article, unless otherwise stated in a credit line to the data. 
blood lymphopenia prior to initial treatment is associated with poor prognosis in various types of cancers, such as advanced carcinomas and sarcomas, cervical cancer, renal carcinoma, and bladder cancer [1, 7-9]. However, the inconsistent effect of pretreatment blood lymphocyte counts in patients with some publications cannot be ignored [10-15]. Moreover, the prognostic impact of lymphopenia in non-hematologic tumors has not been systematically analyzed. In order to reach a more reliable conclusion, a systematic review and meta-analysis to synthesize the evidence pertaining to pretreatment peripheral blood lymphocytes in patients with solid tumors is indispensable.

\section{Materials and methods}

\section{Data sources and search strategy}

The Preferred Reporting Items for Systematic Review and Meta-Analysis (PRISMA) were applied in the present study [16]. We conducted a systematic literature search in the PubMed, Web of Science, and Embase electronic databases to identify relevant studies published as of May 1, 2018. Combinations of the following keywords were used to retrieve articles: "lymphopenia", "lymphocytosis", "lymphocytes", "tumor", "carcinoma", "cancer" and "prognosis" or "survival".

\section{Study selection criteria}

Studies that qualified the following criteria were included: (1) original articles published in English language; (2) studies that enrolled patients with pathologically confirmed solid tumors who had not received any treatment; (2) lymphocyte counts were measured prior to the first treatment (surgery and/or chemotherapy or radiotherapy or palliative therapy); (3) pretreatment lymphocytes were reported as a dichotomous variable; (4) assessed the prognostic impact of pretreatment lymphocytes and had reported hazard ratio (HR) with 95\% confidence interval (CI); at least provided Kaplan-Meier survival curves from which HRs and 95\% CIs could be calculated.

In case of duplicate publications based on the same dataset, only the article with the largest sample size was included. Letters, reviews, case-reports, expert opinions and conference abstracts were excluded from the present study.

Titles and abstracts of articles retrieved on initial search were independently screened by two investigators (W.H. and Y.L.) to eliminate irrelevant articles. Full texts of the remaining articles were reviewed against the above criteria to identify eligible studies. In case of any disagreement between the two reviewers, the final decision was made by a third reviewer (J.Z.).

\section{Data extraction and quality evaluation}

Data pertaining to the following variables were independently extracted by two authors (W.H. and Y.L.): first author; publication year; region; study design; cancer type; sample size; disease stage; cut-off value; survival analysis; treatment details; and HR with corresponding 95\% CI for OS and/or PFS. Survival outcomes obtained on multivariate analysis were accorded precedence over those obtained on univariate analysis.

Two investigators (W.H. and Y.L.) independently assessed the quality of each study according to the Newcastle-Ottawa Scale (NOS); any disagreement was resolved by consensus [17]. Newcastle-Ottawa Scale mainly includes selection, comparability, and evaluation of outcomes. On a scale of 0 to 9 , a study with score of $\geq 6$ was considered as a high-quality study. However, quality assessment was not an exclusion criterion for eligible studies.

\section{Statistical analysis}

We extracted the HRs and 95\% CIs of the ratio for low pretreatment lymphocytes over high pretreatment lymphocytes from each eligible study for OS and/or PFS. The endpoints of survival were OS and/or PFS mainly because the two endpoints were frequently used in the included studies. Meta-analysis was performed to evaluate the prognostic effect of pretreatment lymphocytes in patients with solid tumors for each of the endpoints (OS/PFS). Extracted data were pooled using the Stata 12.0 (STATA Corporation, College Station, TX, USA). Cochrane Q test and the $I^{2}$ statistic were used to test the heterogeneity among the studies included in the pooled analysis. In the absence of significant heterogeneity $\left(P>0.1\right.$ and $\left.I^{2}<50 \%\right)$, the fixed effects model was used for pooled analysis [18]; otherwise, the randomeffects model was used. Pooled HR $>1$ was considered indicative of worse survival outcome of patients with low baseline lymphocytes. If the $95 \%$ CI did not overlap 1, the result was considered statistically significant. Subgroup analyses were performed to investigate the association of pretreatment lymphocyte counts with variables such as region, cancer type, disease stage, cutoff value, survival outcomes, and treatment scheme. Moreover, sensitivity analyses were performed by sequential elimination of one study at a time to explore its potential impact on the heterogeneity. We further used funnel plots and Egger's test to examine the influence of publication bias on the pooled OS and PFS, 
respectively. All statistical tests were two-sided and $P<0.05$ indicated statistical significance.

\section{Results}

\section{Search and selection of studies}

As illustrated in Fig. 1, a total of 2631 articles were retrieved on initial database search. Of these, 2507 articles were removed as irrelevant and duplicate articles. After full-text review, 75 were excluded due to lack of available information. Seven studies that reported lymphocytes count as a continuous variable were excluded. Finally, a total of 42 studies with a combined study population of 13,272 patients were considered eligible for inclusion [1, 7-15, 19-50]. The articles were published in the period from 2005 to 2018. The most common types of cancers in the included studies were lung cancer $(\mathrm{n}=5)$, followed by nasopharyngeal cancer $(\mathrm{n}=4)$ and renal cancer $(\mathrm{n}=4)$. All the included studies
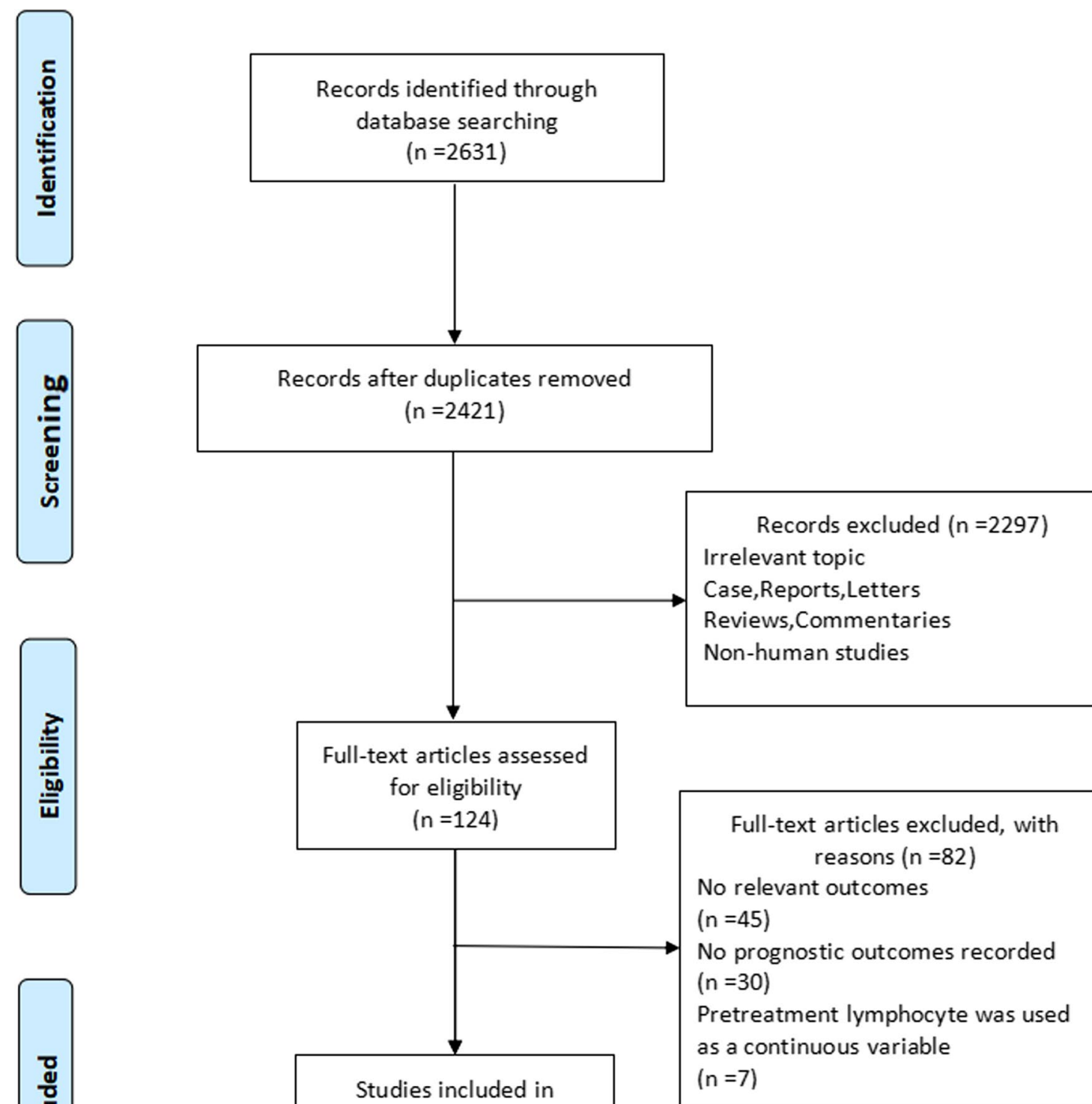

quantitative synthesis

(meta-analysis)

$(n=42)$

Fig. 1 Schematic illustration of the meta-analysis 


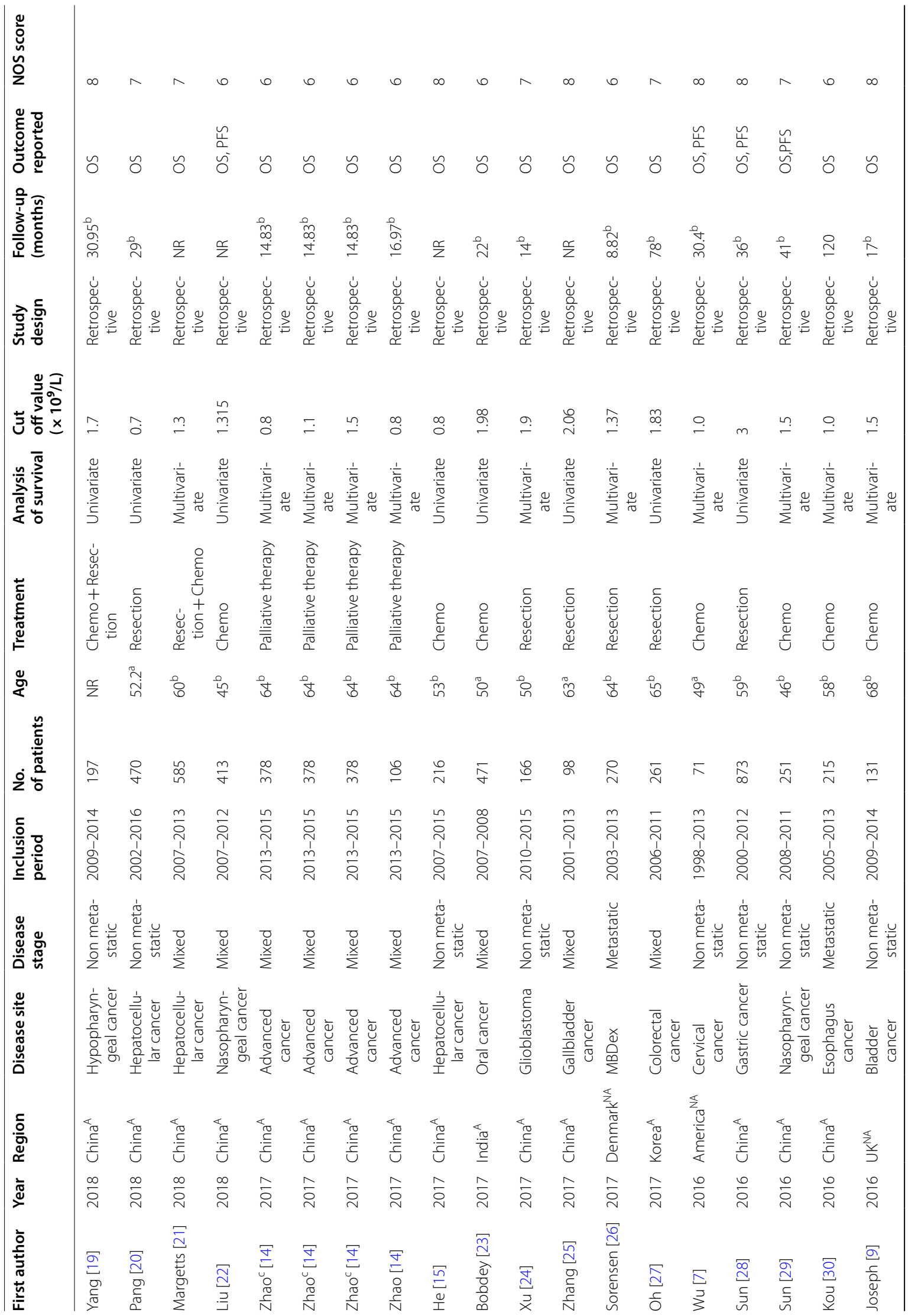




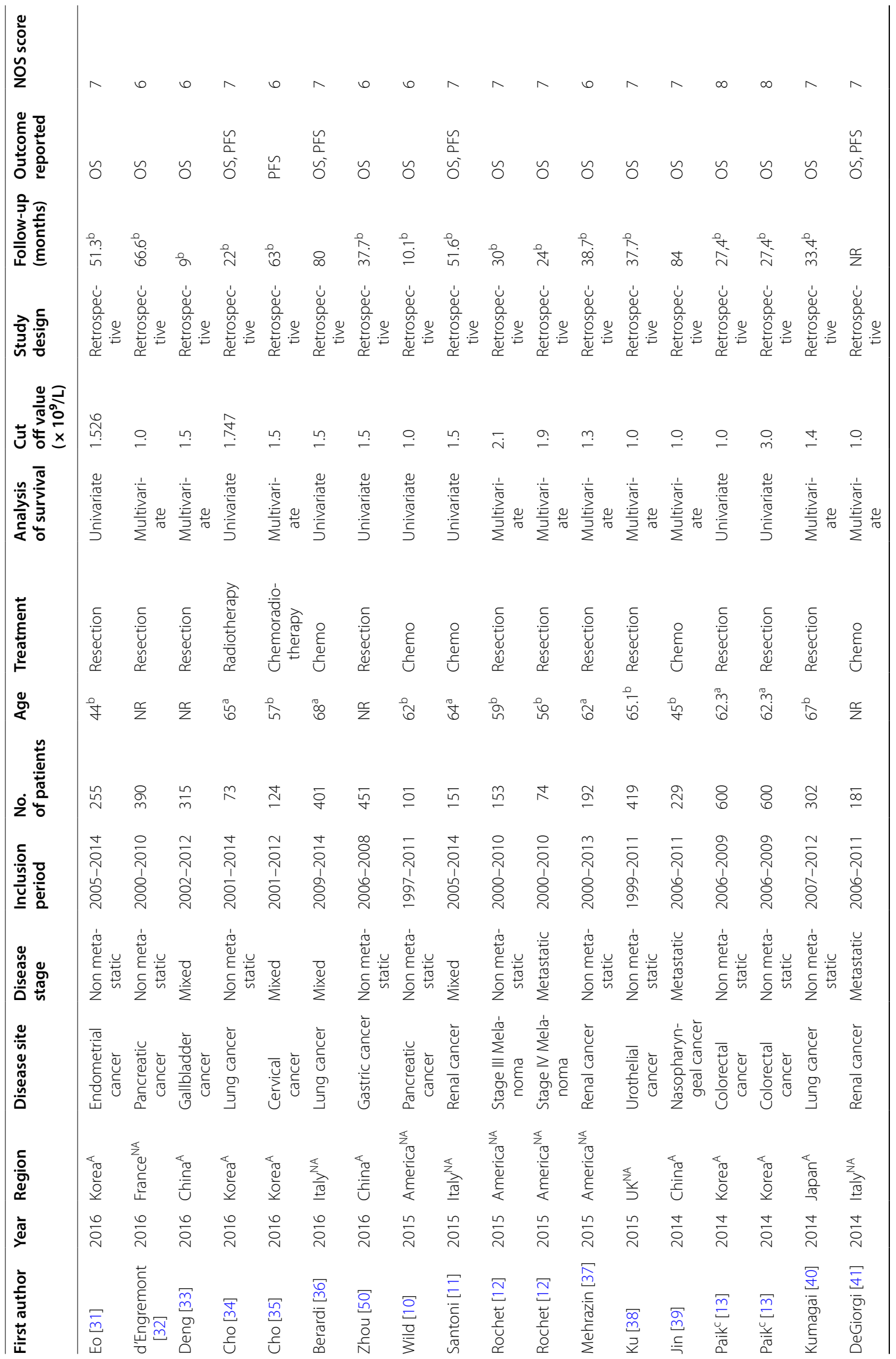




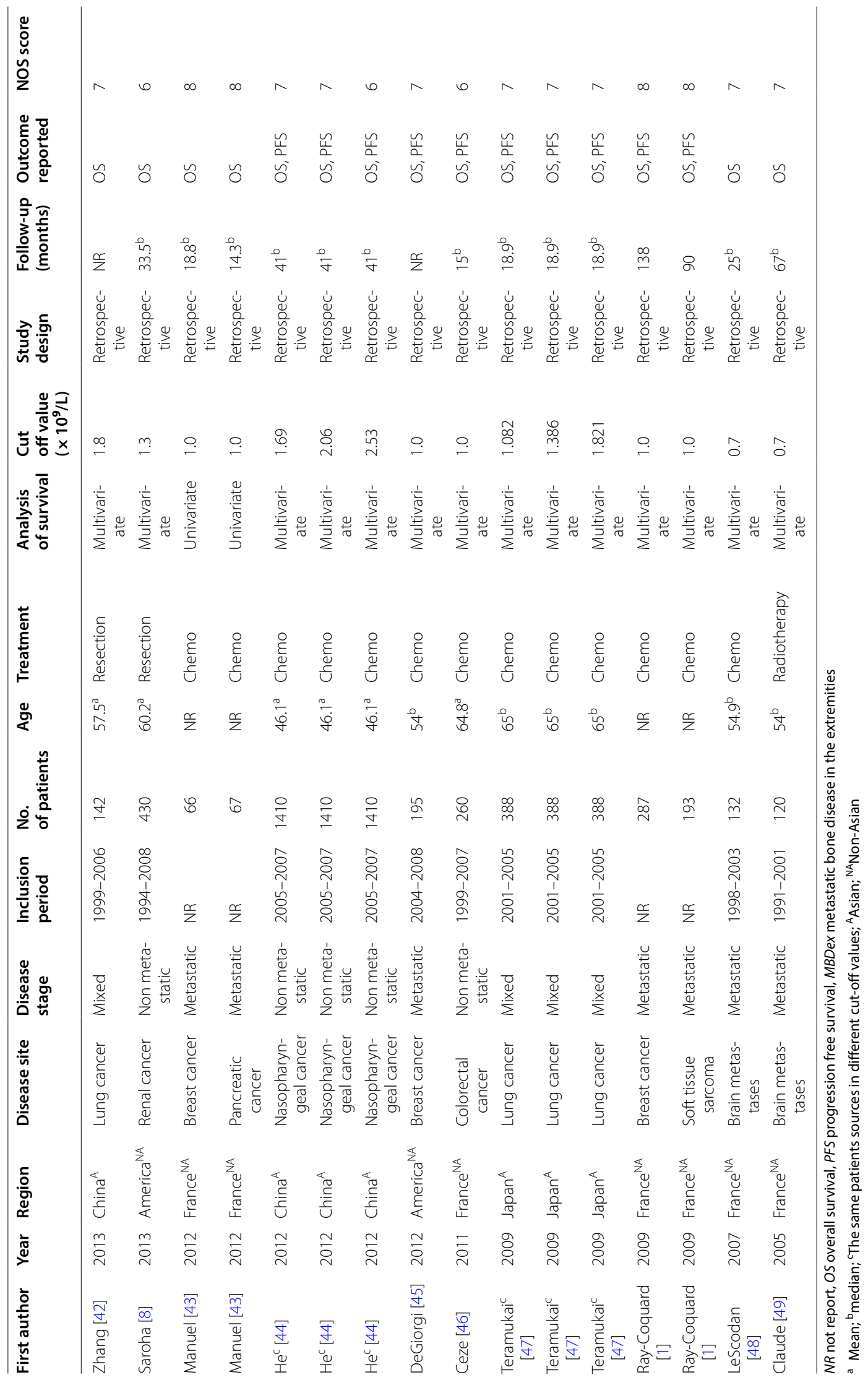


had collected data retrospectively. Characteristics of included articles are described in Table 1.

\section{Relationship between pretreatment lymphocytes and survival outcomes Overall survival}

A total of 41 studies involving 45 cohorts $(13,148$ patients) investigated the association between pretreatment lymphocytes and OS. The median cut-off value of pretreatment lymphocytes in the included cohorts was 1.3425 (range: $0.7-3.0$ ). In 16 articles, the HRs and 95\% CIs were obtained on univariate analysis, while 25 articles had calculated HR on multivariate analysis. Overall, low pretreatment lymphocyte counts were associated with poor OS ( $\mathrm{HR}=1.27,95 \%$ CI 1.16-1.39, $P<0.001$ ) (Fig. 2). There was moderate heterogeneity among studies and thus a random-effects model was used $\left(I^{2}=58.5 \%\right)$. Subgroup analysis stratified by main clinical features (tumor type, cut-off value, survival analysis, and treatment) was performed. On subgroup analysis stratified by cancer type, low pretreatment lymphocytes were most closely associated with poor OS in colorectal cancer $(\mathrm{n}=3, \mathrm{HR}=1.96$, 95\% CI 1.36-2.83, $P<0.001, I^{2}=0$ ), followed by breast cancer $(\mathrm{n}=3, \mathrm{HR}=1.82,95 \%$ CI $1.43-2.31, P<0.001$, $\left.I^{2}=0\right)$, and renal cancer $(\mathrm{n}=4, \mathrm{HR}=1.65,95 \% \mathrm{CI}$ $1.22-2.24, P=0.001, I^{2}=24.3 \%$ ) (Table 2). On subgroup analysis stratified by pretreatment lymphocytes cut-off value, the largest effect size was observed in the cut-off value $\leq 1.0$ subgroup $(\mathrm{n}=17, \mathrm{HR}=1.46 ; 95 \%$ CI $\left.1.21-1.77, P<0.001, I^{2}=67.6 \%\right)$; followed by the $1.0^{<}$cut-off $\leq 2.0$ subgroup $(\mathrm{n}=23, \mathrm{HR}=1.18 ; 95 \% \mathrm{CI}$ $\left.1.06-1.31, P=0.004, I^{2}=49.6 \%\right)$. Cut-off $>2.0$ subgroup was not associated with poor $\mathrm{OS}(\mathrm{n}=5, \mathrm{HR}=1.16$; $95 \%$ CI $\left.0.96-1.39, P=0.121, I^{2}=0\right)$. On subgroup analysis stratified by disease stage, both non-metastatic $(\mathrm{n}=21$, $\mathrm{HR}=1.32,95 \%$ CI 1.12-1.54, $\left.P^{<} 0.001, I^{2}=58.0 \%\right)$ and metastatic subgroups $(\mathrm{n}=10, \mathrm{HR}=1.54,95 \%$ CI $1.24-$ 1.92, $P^{<} 0.001, I^{2}=60.2 \%$ ) were significantly associated with unfavorable OS. However, for the mixed subgroup (patients with both non-metastatic and metastatic disease), the pooled HR was $1.09(\mathrm{n}=11, \mathrm{HR}=1.09,95 \%$ CI $\left.0.98-1.20, P=0.107, I^{2}=26.2 \%\right)$. No significant differences in survival outcomes were observed on subgroup analysis stratified by treatment or by type of survival analysis (univariate analysis vs. multivariate analysis). Further, sensitivity analysis showed that the pooled HRs for OS were not significantly affected by elimination of any individual study from the pooled analysis. The funnel plot was roughly symmetrical and Egger's test showed no significant effect of publication bias on the results of the meta-analysis $(\mathrm{P}=0.188$ for OS).

\section{Progression-free survival}

A total of 14 studies comprising of 18 cohorts (5147 patients) were included in the analysis of HRs for PFS. The median cut-off value for pretreatment lymphocytes was 1.50 (range: $1-3$ ). In 9 articles, the HRs and 95\% CIs were obtained by multivariable analysis; while 5 articles had calculated HRs and 95\% CIs by univariate analysis. Overall, low pretreatment lymphocyte counts were significantly associated with worse PFS (Fig. 3). Owing to the lack of significant heterogeneity $\left(I^{2}=25.7 \%\right)$, the fixed-effects model was used for pooled analysis. On subgroup analysis stratified by cancer type, low pretreatment lymphocytes was most closely associated with poor PFS in patients with breast cancer $(\mathrm{n}=2, \mathrm{HR}=1.76,95 \% \mathrm{CI}$ $1.42-2.20, P^{<} 0.001, I^{2}=0$ ) (Table 3). Likewise, the funnel plot was roughly symmetrical and Egger's test revealed no significant influence of publication bias $(P=0.267$ for PFS).

\section{Discussion}

To the best of our knowledge, this is the first systematic review and meta-analysis that comprehensively summarizes the association between lymphocyte count and cancer survival. Current meta-analysis included a total of 42 studies with a combined study population of 13,272 patients and provides evidence that low lymphocyte counts are associated with shorter OS and PFS in patients with non-hematologic tumors. There was moderate heterogeneity among studies in the analysis of OS $\left(I^{2}=58.5 \%\right)$ but not that of PFS $\left(I^{2}=25.7 \%\right)$. Subsequently, on subgroup analysis by tumor location, the highest effect size with respect to OS was observed in patients with colorectal cancer followed by those with breast cancer and renal cancer. Intriguingly, we found a significant reduction in heterogeneity in subgroups of patients with colorectal cancer $\left(I^{2}=0\right)$, breast cancer $\left(I^{2}=0\right)$ and renal cancer $\left(I^{2}=24.3 \%\right)$ although moderate heterogeneity was observed $\left(I^{2}=58.5 \%\right)$ in the pooled analysis. Moreover, when stratified by disease stage in the analysis of OS and PFS, low lymphocyte count was an adverse prognostic factor in both non-metastatic and metastatic subgroups. This suggests that lymphocytes are involved in several stages of cancer development. Moreover, the negative prognostic effect on OS and PFS was consistent in subgroups stratified by cut-off value and type of survival analysis.

Patients with pretreatment lymphopenia have significantly worse survival than those of patients with normal lymphocyte counts in the context of several malignancies $[1,7-9]$. Lymphocytes are known to play a role in cellular 


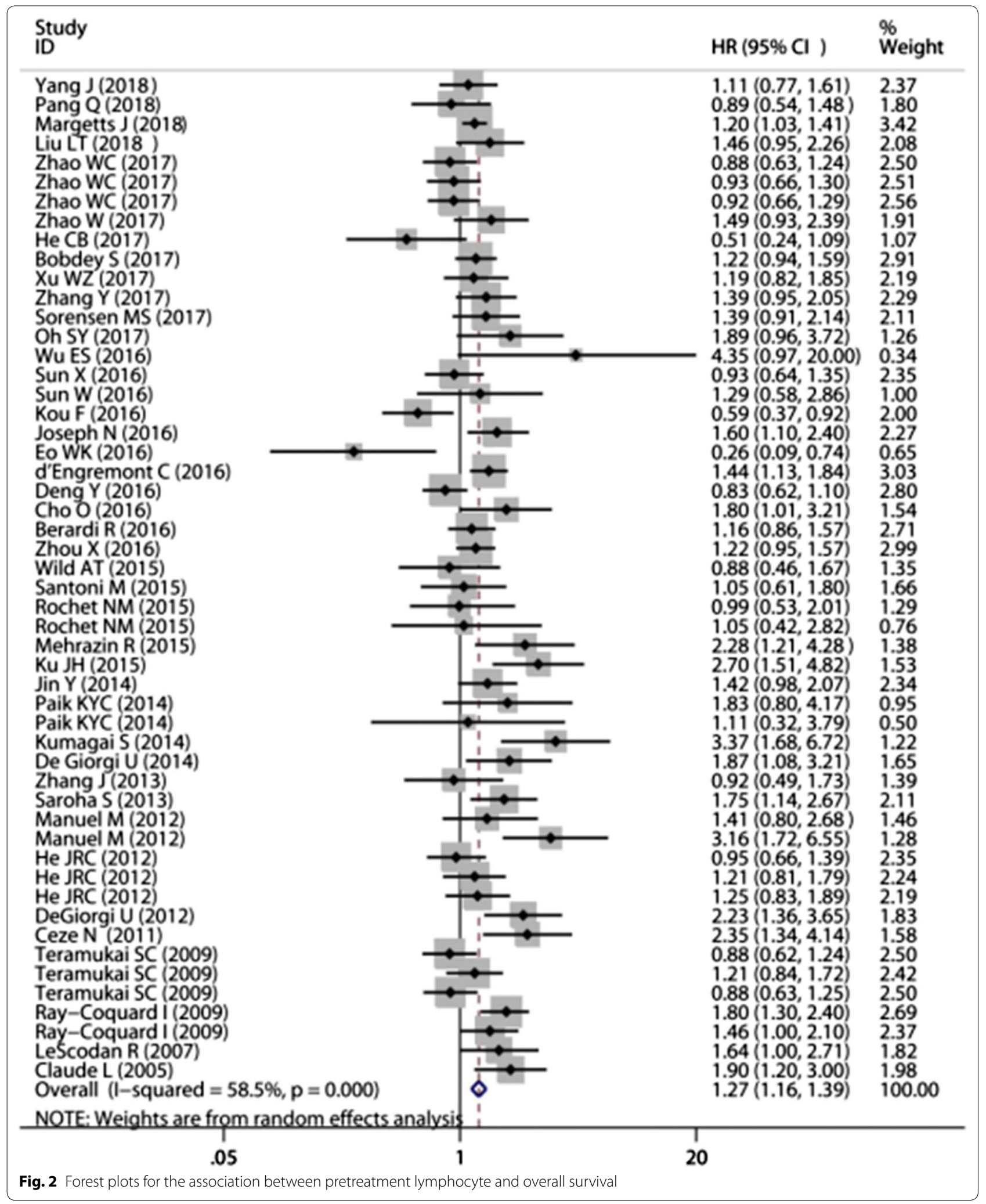


Table 2 Subgroup analysis of the meta-analysis for OS

\begin{tabular}{|c|c|c|c|c|c|c|c|c|}
\hline \multirow[t]{2}{*}{ Subgroup } & \multirow[t]{2}{*}{ No. of studies } & \multirow[t]{2}{*}{ No. of patients } & \multirow[t]{2}{*}{ Pooled HR } & \multirow[t]{2}{*}{$95 \% \mathrm{Cl}$} & \multirow[t]{2}{*}{$P$} & \multicolumn{2}{|c|}{ Heterogeneity test } & \multirow{2}{*}{$\begin{array}{l}\text { Statistical } \\
\text { method }\end{array}$} \\
\hline & & & & & & $r^{2}$ & $P$ & \\
\hline \multicolumn{9}{|l|}{ Treatment } \\
\hline $\begin{array}{l}\text { Resection }[8,12,13,20,24-28,31-33,37 \text {, } \\
\quad 38,40,42,50]\end{array}$ & 17 & 5861 & 1.30 & $1.08-1.55$ & 0.004 & $61.5 \%$ & $<0.001$ & Random \\
\hline $\begin{array}{l}\text { Chemo }[1,7,9-11,15,22,23,29,30,36 \\
39,41,43-47]\end{array}$ & 18 & 5687 & 1.64 & $1.00-2.71$ & $<0.001$ & $60.0 \%$ & $<0.001$ & Random \\
\hline \multicolumn{9}{|l|}{ Analysis of survival } \\
\hline $\begin{array}{l}\text { Multivariate }[1,7-9,12,14,21,24,26,29 \\
30,32,33,37-42,44-49]\end{array}$ & 25 & 7612 & 1.31 & $1.16-1.47$ & $<0.001$ & $63.6 \%$ & $<0.001$ & Random \\
\hline $\begin{array}{l}\text { Univariate }[10,11,13,15,19,20,22,23,25 \\
27,28,31,34,36,43,50]\end{array}$ & 16 & 5536 & 1.20 & $1.02-1.40$ & 0.023 & $46.6 \%$ & 0.016 & Random \\
\hline \multicolumn{9}{|l|}{ Cut-off value } \\
\hline $\begin{array}{l}\leq 1.0[1,7,10,13-15,20,30,32,38,39,41 \\
43,45,46,48,49]\end{array}$ & 17 & 4437 & 1.46 & $1.21-1.77$ & $<0.001$ & $67.6 \%$ & $<0.001$ & Random \\
\hline $\begin{array}{c}1.0 \text { to }<2.0[8,9,11,12,14,19,21-24,26, \\
27,29,31,33,34,36,40,42,44,47,50]\end{array}$ & 22 & 7646 & 1.18 & $1.06-1.31$ & 0.004 & $49.6 \%$ & 0.002 & Random \\
\hline$\geq 2.0[12,13,25,28,44]$ & 5 & 4544 & 1.16 & $0.96-1.39$ & 0.121 & $0.0 \%$ & 0.760 & Random \\
\hline \multicolumn{9}{|l|}{ Disease site } \\
\hline Colorectal cancer $[13,27,46]$ & 3 & 1121 & 1.96 & $1.36-2.83$ & $<0.001$ & $0.0 \%$ & 0.737 & Random \\
\hline Breast cancer $[1,43,45]$ & 3 & 454 & 1.82 & $1.43-2.31$ & $<0.001$ & $0.0 \%$ & 0.509 & Random \\
\hline Renal cancer $[8,11,37,41]$ & 4 & 954 & 1.65 & $1.22-2.24$ & 0.001 & $24.3 \%$ & 0.265 & Random \\
\hline Lung cancer $[34,36,40,42,47]$ & 5 & 1306 & 1.20 & $0.92-1.57$ & 0.177 & $63.9 \%$ & 0.011 & Random \\
\hline Pancreatic cancer $[10,32,43]$ & 3 & 558 & 1.56 & $0.88-2.15$ & 0.129 & $73.5 \%$ & 0.023 & Random \\
\hline Nasopharyngeal cancer $[22,29,39,44]$ & 4 & 2303 & 1.23 & $1.03-1.46$ & 0.017 & $0.0 \%$ & 0.701 & Random \\
\hline Gallbladder cancer $[25,33]$ & 2 & 511 & 1.05 & $0.637-1.75$ & 0.828 & $77.7 \%$ & 0.034 & Random \\
\hline Gastric cancer $[28,50]$ & 2 & 1324 & 1.10 & $0.85-1.43$ & 0.442 & $29.9 \%$ & 0.232 & Random \\
\hline \multicolumn{9}{|l|}{ Disease stage } \\
\hline $\begin{array}{l}\text { Non metastatic }[7-10,12,13,15,19,20 \\
24,28,29,31,32,34,37,38,40,44,46 \\
50]\end{array}$ & 21 & 7437 & 1.32 & $1.12-1.54$ & $<0.001$ & $58.0 \%$ & 0.001 & Random \\
\hline $\begin{array}{l}\text { Metastatic }[1,12,26,30,39,41,43,45 \\
\quad 48,49]\end{array}$ & 10 & 2108 & 1.54 & $1.24-1.92$ & $<0.001$ & $60.2 \%$ & 0.004 & Random \\
\hline Mixed $[11,14,21-23,25,27,33,36,42,47]$ & 11 & 3603 & 1.09 & $0.98-1.20$ & 0.107 & $26.2 \%$ & 0.160 & Random \\
\hline \multicolumn{9}{|l|}{ Region } \\
\hline $\begin{array}{l}\text { Asian [13-15, 19-25, 27-31, 33, 34, 39, } \\
\text { 40, 42, 44, 47, 50] (China, India, Korea, } \\
\text { Japan) }\end{array}$ & 23 & 8422 & 1.10 & $0.99-1.21$ & 0.08 & $48.6 \%$ & 0.001 & Random \\
\hline $\begin{array}{l}\text { Non-Asian [1, 7-12, 26, 32, 36-38, 41, 43, } \\
45,46,48,49] \text { (Denmark, America, UK, } \\
\text { France, Italy) }\end{array}$ & 18 & 4726 & 1.27 & $1.16-1.39$ & $<0.001$ & $32.0 \%$ & 0.080 & Random \\
\hline
\end{tabular}

and humoral anti-tumor immune responses. Activated and proliferating lymphocytes play a role in cytotoxic cell death and inhibit tumor cell proliferation and migration. Chew et al. observed lymphocyte recruitment and proliferation in tumor areas devoid of tumor cell proliferation and rich in tumor cell apoptosis [4]. Therefore, lymphopenia may reflect poor host immunity against cancer and a favorable microenvironment for tumor growth. The underlying mechanism of pretreatment lymphopenia in solid tumors has not been fully clarified and is probably multifactorial. It is widely believed that lymphopenia may result from increased lymphocyte apoptosis and/ or altered lymphocyte homeostasis. Kim et al. demonstrated that increased expression of Fas ligand (FasL) in tumor cells mediated apoptosis of TILs as well as circulating lymphocytes, which conferred immune privilege to tumors [51]. Increased numbers of apoptotic peripheral $\mathrm{T}$ lymphocytes have been detected in patients with gastric cancer [52]. Over-production of immunosuppressive cytokines such as transforming growth factor (TGF- $\beta$ ) and IL-10 by tumor cells specially during tumor growth may suppress different effector pathways of the immune 


\begin{tabular}{|c|c|c|}
\hline \multirow{2}{*}{$\begin{array}{l}\text { Study } \\
\text { ID }\end{array}$} & \multirow[b]{2}{*}{$\mathrm{HR}(95 \% \mathrm{Cl})$} & $\%$ \\
\hline & & Weight \\
\hline Liu LT (2018) & $1.45(0.99,2.13)$ & 5.12 \\
\hline Cho O (2016) & $1.89(0.75,4.67)$ & 1.12 \\
\hline Cho O (2016) & $1.59(0.92,2.75)$ & 2.85 \\
\hline Berardi R (2016) & $1.09(0.85,1.39)$ & 9.26 \\
\hline Wu ES (2016) & $1.54(0.27,9.09)$ & 0.31 \\
\hline Sun W (2016) & $1.18(0.74,1.90)$ & 3.68 \\
\hline Sun X (2016) & $1.10(0.73,1.67)$ & 4.54 \\
\hline Santoni M (2015) & $1.10(0.73,1.67)$ & 4.54 \\
\hline DeGiorgi U (2014) & $1.25(0.76,2.05)$ & 3.38 \\
\hline DeGiorgi U (2012) & $1.82(1.27,2.59)$ & 5.70 \\
\hline He JRC (2012) & $1.06(0.78,1.45)$ & 6.97 \\
\hline He JRC (2012) & $1.35(0.97,1.85)$ & 6.56 \\
\hline He JRC (2012) & $1.61(1.15,2.27)$ & 6.08 \\
\hline Ceze N (2011) & $1.56(1.00,2.43)$ & 4.06 \\
\hline Ray-Coquard I (2009) & $1.73(1.31,2.29)$ & 7.95 \\
\hline Ray-Coquard I (2009) & $1.26(0.90,1.77)$ & 6.15 \\
\hline Teramukai SC (2009) & $0.91(0.68,1.22)$ & 7.52 \\
\hline Teramukai SC (2009) & $1.14(0.83,1.54)$ & 7.04 \\
\hline Teramukai SC (2009) & $1.05(0.78,1.43)$ & 7.18 \\
\hline Overall $(\mathrm{I}-$ squared $=25.7 \%, p=0.148)$ & $1.27(1.15,1.40)$ & 100.00 \\
\hline NOTE: Weights are from random effects analysis & & \\
\hline $\begin{array}{l} \\
11\end{array}$ & & \\
\hline
\end{tabular}

response [53, 54]. Exposure to TGF- $\beta$ reduced the expressions of apoptotic activators (such as perforin and granzyme A and B) on cytotoxic $\mathrm{T}$ cells that infiltrated the tumor tissues. Additionally, tumor growth increases the recruitment of $C D 4+$ regulatory $T$ cells that secrete IL-10 and TGF- $\beta$ and suppress effector CD8 $+\mathrm{T}$ cell responses [55]. IL-10 exerts an inhibitory effect on major histocompatibility complex (MHC) class I antigen presentation. Dummer et al. observed excessive expression of immunosuppressive factor IL-I0 in metastatic lesions and in cultured cells from metastases; they inferred that this cytokine plays a key role in tumor progression [56]. Although numerous studies previously focused on T-cell-mediated immunity, B cells play an equally prominent role in modulating anti-tumor immune responses and in carcinogenesis. B cells are classically known for their role as producers of antibodies. Tumor-infiltrating $B$ cells have relation to improved survival in cervical cancer and non-small cell lung cancer [57, 58]. Results from these clinical observations suggest that the potential mechanisms underlying B-cell anti-tumor immunity may involve tumor-infiltrating B cells could recruit and retain $\mathrm{T}$ cells at the tumor site, thus facilitating and sustaining T-cell responses that inhibit tumor development. Moreover, tumor-infiltrating B cells may function as antigen-presenting cells to aid in anti-tumor immunity [57, 59]. Thus, it may be possible to generate more amplified and prolonged immune responses at the tumor site by promoting cooperative interactions of $\mathrm{B}$ cells and $\mathrm{T}$ cells. Collectively, these findings suggest that lymphopenia may be a result of cancer-induced immune suppression that drives tumor progression.

Neutrophil-lymphocyte ratio (NLR) has been identified as an independent prognostic factor in many solid tumors; a high NLR ratio was shown to be associated with inferior outcomes [60-62]. Nevertheless, it includes 
Table 3 Subgroup analysis of the meta-analysis for PFS

\begin{tabular}{|c|c|c|c|c|c|c|c|c|}
\hline \multirow[t]{2}{*}{ Subgroup } & \multirow[t]{2}{*}{ No. of studies } & \multirow[t]{2}{*}{ No. of patients } & \multirow[t]{2}{*}{ Pooled HR } & \multirow[t]{2}{*}{$95 \% \mathrm{Cl}$} & \multirow[t]{2}{*}{$P$} & \multicolumn{2}{|c|}{$\begin{array}{l}\text { Heterogeneity } \\
\text { test }\end{array}$} & \multirow[t]{2}{*}{$\begin{array}{l}\text { Statistical } \\
\text { method }\end{array}$} \\
\hline & & & & & & $P^{2}$ & $P$ & \\
\hline \multicolumn{9}{|l|}{ Analysis of survival } \\
\hline Multivariate & $9[1,7,29,35,41,44-47]$ & 2487 & 1.30 & $1.14-1.47$ & $<0.001$ & $37.1 \%$ & 0.080 & Fixed \\
\hline Univariate & $5[11,22,28,34,36]$ & 2660 & 1.19 & $1.01-1.40$ & 0.036 & $0.0 \%$ & 0.441 & Fixed \\
\hline \multicolumn{9}{|l|}{ Cut-off value } \\
\hline$\leq 1.0$ & $5[1,7,41,45,46]$ & 1187 & 1.55 & $1.32-1.82$ & $<0.001$ & $0.0 \%$ & 0.617 & Fixed \\
\hline$>1.0$ & $9[11,22,28,29,34-36,44,47]$ & 3960 & 1.11 & $0.99-1.24$ & 0.053 & $0.0 \%$ & 0.643 & Fixed \\
\hline \multicolumn{9}{|l|}{ Disease site } \\
\hline Nasopharyngeal cancer & $3[22,29,44]$ & 2074 & 1.31 & $1.12-1.53$ & 0.001 & $0.0 \%$ & 0.444 & Fixed \\
\hline Breast cancer & $2[1,45]$ & 482 & 1.76 & $1.42-2.20$ & $<0.001$ & $0.0 \%$ & 0.820 & Fixed \\
\hline Renal cancer & $2[11,41]$ & 332 & 1.15 & $0.84-1.59$ & 0.36 & $0.0 \%$ & 0.690 & Fixed \\
\hline \multicolumn{9}{|l|}{ Disease stage } \\
\hline Non metastatic & $6[7,28,29,34,44,46]$ & 2814 & 1.34 & $1.14-1.56$ & $<0.001$ & $0.0 \%$ & 0.612 & Fixed \\
\hline Metastatic & $3[1,41,45]$ & 856 & 1.54 & $1.30-1.84$ & $<0.001$ & $15.2 \%$ & 0.316 & Fixed \\
\hline Mixed & $5[11,22,35,36,47]$ & 1477 & 1.10 & $0.97-1.24$ & 0.138 & $0.0 \%$ & 0.528 & Fixed \\
\hline \multicolumn{9}{|l|}{ Region } \\
\hline Asian(China, Korea, Japan) & $7[22,28,29,34,35,44,47]$ & 3408 & 1.20 & $1.07-1.34$ & 0.002 & $20.2 \%$ & 0.257 & Fixed \\
\hline Non Asian(America, France, Italy) & $7[1,7,11,36,41,45,46]$ & 1739 & 1.37 & $1.20-1.55$ & $<0.001$ & $31.6 \%$ & 0.176 & Fixed \\
\hline
\end{tabular}

two potentially independent biological factors; high NLR indicates an increase in neutrophil and/or decreased total lymphocyte count. A meta-analysis of one hundred studies (combined $n=40,559$ ) conducted by Templeton et al. revealed that high NLR is associated with adverse OS, CSS, PFS, or DFS in many solid tumors [63]. The prognostic impact of NLR may be explained by the association of high NLR with inflammation. However, at the same time, the authors admitted that the confounding effect of concurrent inflammatory conditions cannot be completely excluded because high NLR has also been shown to be of prognostic relevance in non-cancerous conditions such as acute pancreatitis [64] and cardiac events [65]. Joseph suggested that the prognostic value of high neutrophil-lymphocyte ratio may actually be driven by lymphocytopenia rather than neutrophilia in patients with bladder cancer [9]. Similar results have been reported elsewhere; lymphocyte count was shown to exert a stronger impact on the neutrophil-to-lymphocyte ratio in clear cell renal carcinoma and pancreatic cancer $[8,32]$. Therefore, based on these observations, we evaluated the prognostic value of pretreatment peripheral blood lymphocyte counts with respect to clinical outcomes in patients with solid tumors.

Lymphocytopenia is not just a parameter related to cancer survival but may also reflect a biological mechanism that promotes tumor progression. Of note, adjunctive treatment for reversal of lymphopenia or to increase lymphocyte counts has also been proposed by some authors. Restoration of lymphocyte homeostasis may lead to activation of effector cytotoxic and helper $\mathrm{T}$ cells and result in a more potent antitumor immune response. IL-2 was used for treatment of patients with metastatic melanoma. Recombinant human IL-7 (rhIL-7) was shown to improve the immune function of patients with lymphopenia by promoting peripheral $\mathrm{T}$ cell expansion and suppressing the immunosuppressive network [66].

In view of the possible impact of different cut-off values of pretreatment lymphocytes on prognosis, we observed the largest effect size in the cut-off $\leq 1.0$ subgroup; the next was the $1.0<$ cut-off $\leq 2.0$ subgroup. Nonetheless, the cut-off $>2.0$ subgroup was not associated with poor OS. Similar results were obtained on subgroup analysis of PFS. Hence, a relatively lower pretreatment lymphocytes cut-off value may have a better discriminative prognostic value. However, optimal pretreatment lymphocytes cutoff value for various types of cancers needs further research.

Undoubtedly, our research has several limitations. First, our meta-analysis was based on HR and 95\% CIs extracted from retrospective studies. Due to the inherent limitations of retrospective studies including heterogeneity with respect to data selection and analysis, our pooled data might be susceptible to biases and may be biased towards positive results. Second, moderate heterogeneity was observed in the analysis of OS and the sources of this heterogeneity remain unclear; however, no significant heterogeneity was observed in the analysis of PFS. This 
is likely attributable to inclusion of more than 40 cohorts comprising of 13,000 patients with different tumors and from various countries. As yet, we have not found any meta-analysis that determined the prognostic value of pretreatment lymphocytes in any malignancy. Our goal was to gain a comprehensive understanding of the prognostic value of lymphocytes in patients with solid tumors. Therefore, the moderate heterogeneity observed in the analysis of OS is reasonably expected. Third, in 16 out of the 42 studies, the HRs were calculated on univariate analysis. Compared with data from multivariate analysis, HR and 95\% CI calculated on univariate analysis is more likely to lead to an overestimation of the prognostic value. Therefore, we conducted subgroup analysis of univariate analysis and multivariate analysis and the statistical significance was stable; moreover, the multivariate analysis subgroup even had a larger effect size.

\section{Conclusion}

Peripheral blood lymphocytes is a simple and routine index in clinical work. To the best our knowledge, we have not found any meta-analysis that determined the prognostic value of pretreatment lymphocytes in any malignancy. Our meta-analysis provides evidence that pretreatment lymphocyte might be a potential biomarker for survival in patients with solid tumors. However, the present meta-analysis was based on observational studies; we could not demonstrate a cause-effect relationship between pretreatment lymphocyte and survival in patients with solid tumors. Further prospective largescale investigations are required to explore whether reversing lymphopenia can be a new target for cancer treatment and to increase the understanding of its role in disease pathogenesis.

\section{Abbreviations}

HR: hazard ratio; CL: confidence interval; OS: overall survival; PFS: progression-free survival; NOS: Newcastle-Ottawa Scale; TILs: tumour-infiltrating lymphocytes; PRISMA: Preferred Reporting Items for Systematic Review and Meta-Analysis; FasL: Fas ligand; TGF- $\beta$ : transforming growth factor; MHC: major histocompatibility complex; NLR: neutrophil-lymphocyte ratio.

\section{Acknowledgements \\ None.}

\section{Authors' contributions}

JZ and WH collected, extracted performed quality assessment articles; WH and $\mathrm{YL}$ analyzed the data; JZ, JC, and WH conceived, designed this study and wrote the paper. $C L, D L$ and JC reviewed the final manuscript. YW and BW revised the manuscript. All authors read and approved the final manuscript.

\section{Funding}

This work was supported by the National Natural Science Foundation of China (No. 81660125).

\section{Availability of data and materials}

The datasets analyzed during the current study are available from the corresponding author on reasonable request.
Ethics approval and consent to participate Not applicable.

\section{Consent for publication}

Not applicable.

\section{Competing interests}

The authors declared no potential competing interests with respect to the research, authorship, publication of this article.

\section{Author details}

${ }^{1}$ Department of Urology, The First Affiliated Hospital of Guangxi Medical University, 6 Shuangyong Road, Nanning 530021, Guangxi Zhuang Autonomous Region, China. ${ }^{2}$ Department of Gastrointestinal Surgery, The First Affiliated Hospital of Guangxi Medical University, 6 Shuangyong Road, Nanning 530021, Guangxi Zhuang Autonomous Region, China.

Received: 23 May 2019 Accepted: 2 January 2020

Published online: 10 January 2020

References

1. Ray-Coquard I, Cropet C, Van Glabbeke M, et al. Lymphopenia as a prognostic factor for overall survival in advanced carcinomas, sarcomas, and lymphomas. Cancer Res. 2009;69(13):5383-91. https://doi. org/10.1158/0008-5472.can-08-3845 (published Online First: Epub Date).

2. Gooden MJ, de Bock GH, Leffers N, Daemen T, Nijman HW. The prognostic influence of tumour-infiltrating lymphocytes in cancer: a systematic review with meta-analysis. Br J Cancer. 2011;105(1):93-103. https://doi. org/10.1038/bjc.2011.189 (Epub 2011 May 31. Review).

3. Mantovani A, Allavena P, Sica A, Balkwill F. Cancer-related inflammation. Nature. 2008;454(7203):436-44. https://doi.org/10.1038/nature07205 (Review).

4. Chew $V$, Tow $C$, Teo M, et al. Inflammatory tumour microenvironment is associated with superior survival in hepatocellular carcinoma patients. J Hepatol. 2010;52(3):370-9. https://doi.org/10.1016/j.jhep.2009.07.013 (published Online First: Epub Date).

5. Galon J, Costes A, Sanchez-Cabo F, et al. Type, density, and location of immune cells within human colorectal tumors predict clinical outcome. Science (New York, NY). 2006;313(5795):1960-4. https://doi.org/10.1126/ science.1129139 (published Online First: Epub Date).

6. Zhang L, Conejo-Garcia JR, Katsaros D, et al. Intratumoral T cells, recurrence, and survival in epithelial ovarian cancer. N Engl J Med. 2003;348(3):203-13. https://doi.org/10.1056/nejmoa020177 (published Online First: Epub Date)

7. Wu ES, Oduyebo T, Cobb LP, et al. Lymphopenia and its association with survival in patients with locally advanced cervical cancer. Gynecol Oncol. 2016;140(1):76-82. https://doi.org/10.1016/j.ygyno.2015.11.013 (published Online First: Epub Date).

8. Saroha S, Uzzo RG, Plimack ER, et al. Lymphopenia is an independent predictor of inferior outcome in clear cell renal carcinoma. J Urol. 2013;189(2):454-61. https://doi.org/10.1016/j.juro.2012.09.166 (published Online First: Epub Date).

9. Joseph N, Dovedi SJ, Thompson C, et al. Pre-treatment lymphocytopaenia is an adverse prognostic biomarker in muscle-invasive and advanced bladder cancer. Ann Oncol. 2016;27(2):294-9. https://doi.org/10.1093/ annonc/mdv546 (published Online First: Epub Date).

10. Wild AT, Ye X, Ellsworth SG, et al. The association between chemoradiation-related lymphopenia and clinical outcomes in patients with locally advanced pancreatic adenocarcinoma. Am J Clin Oncol. 2015;38(3):25965. https://doi.org/10.1097/COC.0b013e3182940ff9 (published Online First: Epub Date).

11. Santoni M, Buti S, Conti A, et al. Prognostic significance of host immune status in patients with late relapsing renal cell carcinoma treated with targeted therapy. Target Oncol. 2015;10(4):517-22. https://doi.org/10.1007/ s11523-014-0356-3 (published Online First: Epub Date).

12. Rochet NM, Kottschade LA, GrotzTE, et al. The prognostic role of the preoperative absolute lymphocyte count and absolute monocyte count in patients with resected advanced melanoma. Am J Clin Oncol. 
2015;38(3):252-8. https://doi.org/10.1097/COC.0b013e31829b5605 (published Online First: Epub Date).

13. Paik KY, Lee IK, Lee YS, et al. Clinical implications of systemic inflammatory response markers as independent prognostic factors in colorectal cancer patients. Cancer Res Treat. 2014;46(1):65-73. https://doi.org/10.4143/ crt.2014.46.1.65 (published Online First: Epub Date).

14. Zhao W, Wang P, Jia H, et al. Lymphocyte count or percentage: which can better predict the prognosis of advanced cancer patients following palliative care? BMC Cancer. 2017;17(1):514. https://doi.org/10.1186/s1288 5-017-3498-8 (publishedOnline First: Epub Date).

15. He CB, Lin XJ. Inflammation scores predict the survival of patients with hepatocellular carcinoma who were treated with transarterial chemoembolization and recombinant human type-5 adenovirus H101. PLoS ONE. 2017;12(3):e0174769. https://doi.org/10.1371/journal.pone.0174769 (published Online First: Epub Date).

16. Moher D, Liberati A, Tetzlaff J, et al. Preferred reporting items for systematic reviews and meta-analyses: the PRISMA statement. J Clin Epidemiol. 2009;62(10):1006-12. https://doi.org/10.1016/j.jclinepi.2009.06.005 (published Online First: Epub Date)

17. Hayden JA, Cote P, Bombardier C. Evaluation of the quality of prognosis studies in systematic reviews. Ann Intern Med. 2006;144(6):427-37.

18. Higgins JP, Thompson SG, Deeks JJ, et al. Measuring inconsistency in meta-analyses. BMJ (Clinical Research ed). 2003;327(7414):557-60. https ://doi.org/10.1136/bmj.327.7414.557 (published Online First: Epub Date).

19. Yang J, Hsueh CY, Cao W, et al. Pretreatment lymphocyte-to-monocyte ratio as an independent prognostic factor for hypopharyngeal squamous cell carcinoma. Acta Otolaryngol. 2018. https://doi.org/10.1080/00016 489.2018.1449965 (published Online First: Epub Date)

20. Pang Q, Zhou L, Qu K, et al. Validation of inflammation-based prognostic models in patients with hepatitis B-associated hepatocellular carcinoma: a retrospective observational study. Eur J Gastroenterol Hepatol. 2018;30(1):60-70. https://doi.org/10.1097/meg.00000000000001021 (published Online First: Epub Date)

21. Margetts J, Ogle LF, Chan SL, et al. Neutrophils: driving progression and poor prognosis in hepatocellular carcinoma? Br J Cancer. 2018;1 18(2):248-57. https://doi.org/10.1038/bjc.2017.386 (published Online First: Epub Date)

22. Liu LT, Chen QY, Tang LQ, et al. The prognostic value of treatment-related lymphopenia in nasopharyngeal carcinoma patients. Cancer Res Treat. 2018:50(1):19-29. https://doi.org/10.4143/crt.2016.595 (published Online First: Epub Date)

23. Bobdey S, Ganesh B, Mishra P, et al. Role of monocyte count and neutrophil-to-lymphocyte ratio in survival of oral cancer patients. Int Arch Otorhinolaryngol. 2017;21(1):21-7. https://doi.org/10.1055/s-0036-15873 18 (published Online First: Epub Date).

24. $X u W Z, L i F, X u Z K$, et al. Preoperative albumin-to-globulin ratio and prognostic nutrition index predict prognosis for glioblastoma. OncoTargets Ther. 2017;10:725-33. https://doi.org/10.2147/ott.s127441 (published Online First: Epub Date)

25. Zhang $Y, M a C$, Wang $M$, et al. Prognostic significance of immune cells in the tumor microenvironment and peripheral blood of gallbladder carcinoma patients. 2017;19(4):477-88. https://doi.org/10.1007/s1209 4-016-1553-6 (published Online First: Epub Date).

26. Sorensen MS, Hovgaard TB, Hindso K, et al. Prognostic value of biochemical variables for survival after surgery for metastatic bone disease of the extremities. J Surg Oncol. 2017;115(4):442-8. https://doi.org/10.1002/ jso.24537 (published Online First: Epub Date).

27. Oh SY, Kim YB, Suh KW. Prognostic significance of systemic inflammatory response in stage II colorectal cancer. J Surg Res. 2017;208:158-65. https ://doi.org/10.1016/j.jss.2016.08.100 (published Online First: Epub Date).

28. Sun X, Wang J, Liu J, et al. Albumin concentrations plus neutrophil lymphocyte ratios for predicting overall survival after curative resection for gastric cancer. OncoTargets Ther. 2016;9:4661-9. https://doi.org/10.2147/ ott.s108631 (published Online First: Epub Date).

29. Sun W, Zhang L, Luo M, et al. Pretreatment hematologic markers as prognostic factors in patients with nasopharyngeal carcinoma: neutrophil-lymphocyte ratio and platelet-lymphocyte ratio. Head Neck. 2016;38(Suppl 1):E1332-40. https://doi.org/10.1002/hed.24224 (published Online First: Epub Date).
30. Kou F, Lu Z, Li J, et al. Pretreatment lymphopenia is an easily detectable predictive and prognostic marker in patients with metastatic esophagus squamous cell carcinoma receiving first-line chemotherapy. Cancer Med. 2016;5(5):778-86. https://doi.org/10.1002/cam4.638 (published Online First: Epub Date).

31. Eo WK, Kwon S, Koh SB, et al. The lymphocyte-monocyte ratio predicts patient survival and aggressiveness of endometrial cancer. J Cancer. 2016;7(5):538-45. https://doi.org/10.7150/jca.14206 (published Online First: Epub Date).

32. d'Engremont C, Vernerey D, Pointet AL, et al. Additive value of pre-operative and one-month post-operative lymphocyte count for death-risk stratification in patients with resectable pancreatic cancer: a multicentric study. BMC Cancer. 2016;16(1):823. https://doi.org/10.1186/s12885-0162860-6 (published Online First: Epub Date).

33. Deng Y, Pang Q, Bi JB, et al. A promising prediction model for survival in gallbladder carcinoma patients: pretreatment prognostic nutrient index. Tumour Biol. 2016. https://doi.org/10.1007/s13277-016-5396-0 (published Online First: Epub Date)

34. Cho O, Oh YT, Chun M, et al. Radiation-related lymphopenia as a new prognostic factor in limited-stage small cell lung cancer. Tumour Biol. 2016;37(1):971-8. https://doi.org/10.1007/s13277-015-3888-y (published Online First: Epub Date)

35. Cho O, Chun M, Chang SJ, et al. Prognostic value of severe lymphopenia during pelvic concurrent chemoradiotherapy in cervical cancer. Anticancer Res. 2016;36(7):3541-7.

36. Berardi R, Rinaldi S, Santoni M, et al. Prognostic models to predict survival in patients with advanced non-small cell lung cancer treated with firstline chemo- or targeted therapy. Oncotarget. 2016;7(18):26916-24. https ://doi.org/10.18632/oncotarget.8309 (published Online First: Epub Date).

37. Mehrazin R, Uzzo RG, Kutikov A, et al. Lymphopenia is an independent predictor of inferior outcome in papillary renal cell carcinoma. Urol Oncol. 2015;33(9):388.e19-25. https://doi.org/10.1016/j.urolonc.2014.06.004 (published Online First: Epub Date)

38. $\mathrm{Ku} \mathrm{JH}$, Kang M, Kim HS, et al. The prognostic value of pretreatment of systemic inflammatory responses in patients with urothelial carcinoma undergoing radical cystectomy. Br J Cancer. 2015;112(3):461-7. https:// doi.org/10.1038/bjc.2014.631 (published Online First: Epub Date).

39. Jin $Y, Y e X, H e C$, et al. Pretreatment neutrophil-to-lymphocyte ratio as predictor of survival for patients with metastatic nasopharyngeal carcinoma. Head Neck. 2015;37(1):69-75. https://doi.org/10.1002/hed.23565 (published Online First: Epub Date)

40. Kumagai S, Marumo S, Shoji T, et al. Prognostic impact of preoperative monocyte counts in patients with resected lung adenocarcinoma. Lung Cancer (Amsterdam, Netherlands). 2014;85(3):457-64. https://doi. org/10.1016/j.lungcan.2014.06.015 (published Online First: Epub Date)

41. De Giorgi U, Rihawi K, Aieta M, et al. Lymphopenia and clinical outcome of elderly patients treated with sunitinib for metastatic renal cell cancer. J Geriatr Oncol. 2014;5(2):156-63. https://doi.org/10.1016/j.jgo.2014.01.001 (published Online First: Epub Date).

42. Zhang J, Huang $\mathrm{SH}$, Li H, et al. Preoperative lymphocyte count is a favorable prognostic factor of disease-free survival in non-small-cell lung cancer. Medical Oncol (Northwood, London, England). 2013;30(1):352. https://doi.org/10.1007/s12032-012-0352-3 (published Online First: Epub Date).

43. Manuel M, Tredan O, Bachelot T, et al. Lymphopenia combined with low TCR diversity (divpenia) predicts poor overall survival in metastatic breast cancer patients. Oncoimmunology. 2012;1 (4):432-40.

44. He JR, Shen GP, Ren ZF, et al. Pretreatment levels of peripheral neutrophils and lymphocytes as independent prognostic factors in patients with nasopharyngeal carcinoma. Head Neck. 2012;34(12):1769-76. https://doi. org/10.1002/hed.22008 (published Online First: Epub Date).

45. De Giorgi U, Mego M, Scarpi E, et al. Relationship between lymphocytopenia and circulating tumor cells as prognostic factors for overall survival in metastatic breast cancer. Clin Breast Cancer. 2012;12(4):264-9. https:// doi.org/10.1016/j.clbc.2012.04.004 (published Online First: Epub Date)

46. Ceze N, Thibault G, Goujon G, et al. Pre-treatment lymphopenia as a prognostic biomarker in colorectal cancer patients receiving chemotherapy. Cancer Chemother Pharmacol. 2011;68(5):1305-13. https://doi org/10.1007/s00280-011-1610-3 (published Online First: Epub Date). 
47. Teramukai S, Kitano T, Kishida Y, et al. Pretreatment neutrophil count as an independent prognostic factor in advanced non-small-cell lung cancer: an analysis of Japan Multinational Trial Organisation LC00-03. Eur Journal Cancer (Oxford, England: 1990). 2009;45(11):1950-8. https://doi. org/10.1016/j.ejca.2009.01.023 (published Online First: Epub Date).

48. Le Scodan R, Massard C, Mouret-Fourme E, et al. Brain metastases from breast carcinoma: validation of the radiation therapy oncology group recursive partitioning analysis classification and proposition of a new prognostic score. Int J Radiat Oncol Biol Phys. 2007;69(3):839-45. https ://doi.org/10.1016/j.jijobp.2007.04.024 (published Online First: Epub Date).

49. Claude L, Perol D, Ray-Coquard I, et al. Lymphopenia: a new independent prognostic factor for survival in patients treated with whole brain radiotherapy for brain metastases from breast carcinoma. Radiother Oncol. 2005;76(3):334-9. https://doi.org/10.1016/j.radonc.2005.06.004 (published Online First: Epub Date)

50. Zhou X, Xu L, Huang Z, et al. The hematologic markers as prognostic factors in patients with resectable gastric cancer. Cancer Biomark Sect A Dis Markers. 2016;17(3):359-67. https://doi.org/10.3233/cbm-160648 (published Online First: Epub Date)

51. Kim R, Emi M, Tanabe K, et al. The role of Fas ligand and transforming growth factor beta in tumor progression: molecular mechanisms of immune privilege via Fas-mediated apoptosis and potential targets for cancer therapy. Cancer. 2004;100(11):2281-91. https://doi.org/10.1002/ cncr.20270 (published Online First: Epub Date).

52. Takahashi A, Kono K, Amemiya H, et al. Elevated caspase-3 activity in peripheral blood T cells coexists with increased degree of T-cell apoptosis and down-regulation of TCR zeta molecules in patients with gastric cancer. Clin Cancer Res. 2001;7(1):74-80.

53. Gorelik L, Flavell RA. Transforming growth factor-beta in T-cell biology. Nat Rev Immunol. 2002;2(1):46-53. https://doi.org/10.1038/nri704 (published Online First: Epub Date).

54. Flavell RA, Sanjabi S, Wrzesinski SH, et al. The polarization of immune cells in the tumour environment by TGFbeta. Nat Rev Immunol. 2010;10(8):554-67. https://doi.org/10.1038/nri2808 (published Online First: Epub Date)

55. Salazar-Onfray F, Lopez MN, Mendoza-Naranjo A. Paradoxical effects of cytokines in tumor immune surveillance and tumor immune escape. Cytokine Growth Factor Rev. 2007;18(1-2):171-82. https://doi. org/10.1016/j.cytogfr.2007.01.015 (published Online First: Epub Date)

56. Dummer W, Bastian BC, Ernst N, et al. Interleukin-10 production in malignant melanoma: preferential detection of IL-10-secreting tumor cells in metastatic lesions. Int J Cancer. 1996;66(5):607-10. https://doi. org/10.1002/(sici)1097-0215(19960529)66:5\%3c607:aid-ijc4\%3e3.0.co;2-x (published Online First: Epub Date)

57. Al-Shibli K, Donnem T, Al-Saad S, et al. Prognostic effect of epithelial and stromal lymphocyte infiltration in non-small cell lung cancer. Clin Cancer Res. 2008;14(16):5220-7.
58. Nedergaard BS, Ladekarl M, Nyengaard JR, et al. A comparative study of the cellular immune response in patients with stage IB cervical squamous cell carcinoma. Low numbers of several immune cell subtypes are strongly associated with relapse of disease within 5 years. Gynecol Oncol. 2008;108(1):106-11.

59. Wennhold K, Shimabukuro-Vornhagen A, Von Bergwelt-Baildon M. B cellbased cancer immunotherapy. Transf Med Hemother. 2019;46(1):36-46.

60. Mei Z, Shi L, Wang B, et al. Prognostic role of pretreatment blood neutrophil-to-lymphocyte ratio in advanced cancer survivors: a systematic review and meta-analysis of 66 cohort studies. Cancer Treat Rev. 2017;58:1-13. https://doi.org/10.1016/j.ctrv.2017.05.005 (published Online First: Epub Date)

61. Mano Y, Shirabe K, Yamashita Y, et al. Preoperative neutrophil-to-lymphocyte ratio is a predictor of survival after hepatectomy for hepatocellular carcinoma: a retrospective analysis. Ann Surg. 2013;258(2):301-5. https:// doi.org/10.1097/sla.0b013e318297ad6b (published Online First: Epub Date).

62. Sun XD, Shi XJ, Chen YG, et al. Elevated preoperative neutrophil-lymphocyte ratio is associated with poor prognosis in hepatocellular carcinoma patients treated with liver transplantation: a meta-analysis. Gastroenterol Res Pract. 2016;2016:4743808. https://doi.org/10.1155/2016/4743808 (published Online First: Epub Date)

63. Templeton AJ, McNamara MG, Šeruga B, Vera-Badillo FE, Aneja P, Ocaña A, Leibowitz-Amit R, Sonpavde G, Knox JJ, Tran B, Tannock IF, Amir E. Prognostic role of neutrophil-to-lymphocyte ratio in solid tumors: a systematic review and meta-analysis. J Natl Cancer Inst. 2014;106(6):dju124. https://doi.org/10.1093/jnci/dju124 (Print 2014 Jun. Review).

64. Azab B, Jaglall N, Atallah JP, Lamet A, Raja-Surya V, Farah B, Lesser M, Widmann WD. Neutrophil-lymphocyte ratio as a predictor of adverse outcomes of acute pancreatitis. Pancreatology. 2011;11(4):445-52. https ://doi.org/10.1159/000331494 (Epub 2011 Sep 28).

65. Park JJ, Jang HJ, Oh IY, Yoon CH, Suh JW, Cho YS, Youn TJ, Cho GY, Chae IH, Choi DJ. Prognostic value of neutrophil to lymphocyte ratio in patients presenting with ST-elevation myocardial infarction undergoing primary percutaneous coronary intervention. Am J Cardiol. 2013;111(5):636-42. https://doi.org/10.1016/j.amjcard.2012.11.012 (Epub 2012 Dec 27).

66. Gao J, Zhao L, Wan YY, et al. Mechanism of action of IL-7 and its potential applications and limitations in cancer immunotherapy. Int J Mol Sci. 2015;16(5):10267-80. https://doi.org/10.3390/ijms160510267 (published Online First: Epub Date)

\section{Publisher's Note}

Springer Nature remains neutral with regard to jurisdictional claims in published maps and institutional affiliations.

Ready to submit your research? Choose BMC and benefit from:

- fast, convenient online submission

- thorough peer review by experienced researchers in your field

- rapid publication on acceptance

- support for research data, including large and complex data types

- gold Open Access which fosters wider collaboration and increased citations

- maximum visibility for your research: over 100M website views per year

At BMC, research is always in progress.

Learn more biomedcentral.com/submissions 